University of Vermont

UVM ScholarWorks

University Libraries Faculty and Staff

Publications

University Libraries

$10-2003$

\title{
What's Best for Students: Comparing the Effectiveness of a Traditional Print Pathfinder and a Web-based Research Tool
}

Trina J. Magi

University of Vermont, tmagi@uvm.edu

Follow this and additional works at: https://scholarworks.uvm.edu/libfacpub

Part of the Information Literacy Commons

\section{Recommended Citation}

Magi, Trina J., "What's Best for Students: Comparing the Effectiveness of a Traditional Print Pathfinder and a Web-based Research Tool" (2003). University Libraries Faculty and Staff Publications. 15. https://scholarworks.uvm.edu/libfacpub/15

This Article is brought to you for free and open access by the University Libraries at UVM ScholarWorks. It has been accepted for inclusion in University Libraries Faculty and Staff Publications by an authorized administrator of UVM ScholarWorks. For more information, please contact scholarworks@uvm.edu. 
What's Best for Students? Comparing the Effectiveness of a ...

Magi, Trina J

Portal : Libraries and the Academy; Oct 2003; 3, 4; ProQuest Central pg. 671

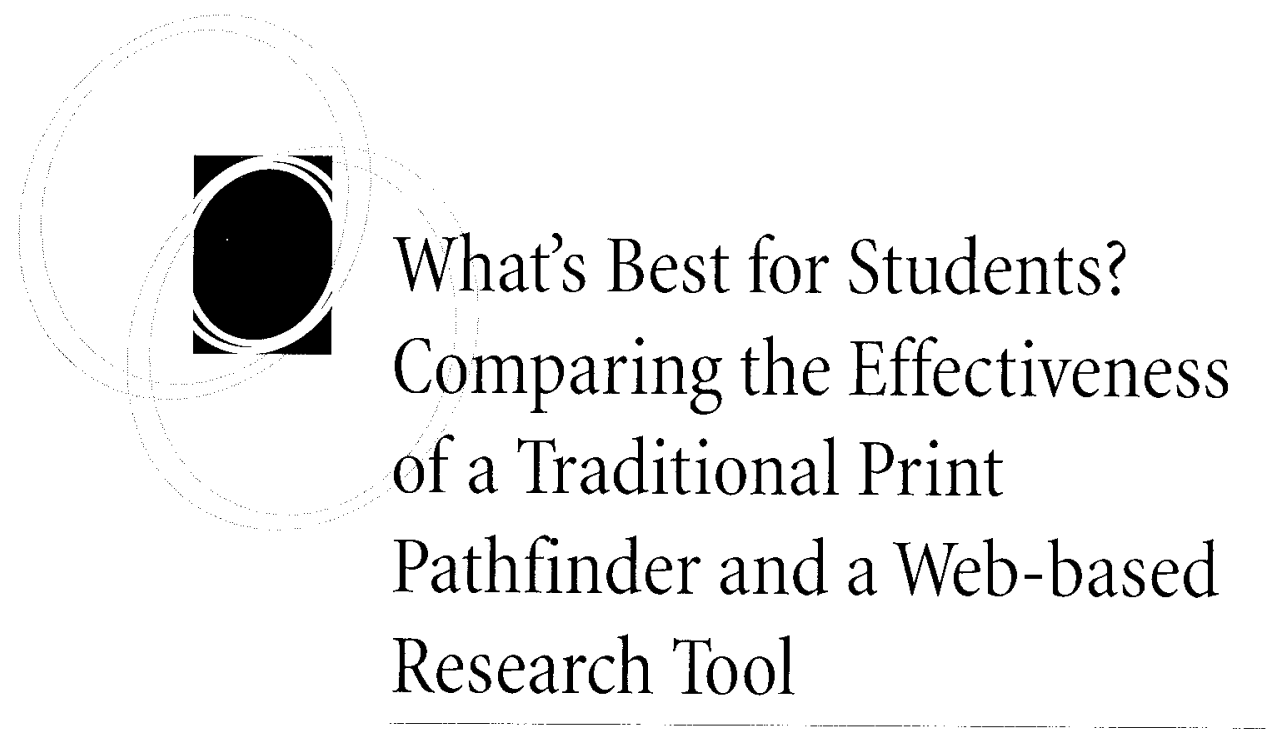

Trina J. Magi

abstract: This quantitative study compared a print pathfinder and a web-based research tool in library instruction for two sections of a first-year business course. The traditional print pathfinder received higher ratings on use, ease of use, and helpfulness, but both tools resulted in students citing a similar number of recommended sources.

$\mathrm{F}$ or years, academic librarians have developed research guides and subject bibliographies to help students more quickly find information in various disciplines. This study tested the effectiveness of two different tools designed to guide students to useful business information sources: a traditional, printed pathfinder and a database-driven, interactive web-based tool. The study was intended to help the librarian decide whether it is in the best interest of students to replace the traditional printed pathfinder with an interactive web tool.

Each semester, Bailey/Howe Library at University of Vermont provides library instruction sessions for several business courses. Students in these courses are typically assigned to write research papers or business/marketing plans, and are advised to consult a host of business reference sources to fulfill their assignments. To assist the students, the librarian prepares for each class an annotated list or "pathfinder" of recommended business information sources, including reference books, government documents, subscription databases, and free web sites.

In library instruction evaluations, University of Vermont students consistently rate these traditional print pathfinders as very useful, and librarians frequently see students

portal: Libraries and the Academy, Vol. 3, No. 4 (2003), pp. 671-686. Copyright $(2003$ by The Johns Hopkins University Press, Baltimore, MD 21218. 
working in the library with the pathfinders in hand. The pathfinders are also useful to students during the library instruction sessions, serving as a "road map" and allowing students to make notes about the sources that are shown in class.

While the pathfinders appear to be working well for students, they work less well for librarians. Each pathfinder is unique and tailored to the needs of the class, but there is a great deal of overlap among them, with many of the same sources appearing on several pathfinders. Every semester, the librarian must

While the pathfinders appear to be working well for students, they work less well for librarians. check each one for accuracy and update them as source titles, content, and library locations change. The preparation and updating of these pathfinders at the beginning of each semester is tedious and consumes time that would be better spent in collection development and other reference or instruction activities. Furthermore, while these course-specific pathfinders are useful to students enrolled in the classes for which they're designed, they are less useful to reference librarians fielding a va-

riety of unrelated business questions, and they are of no use to business students in classes that receive no library instruction.

To address the above-mentioned problems, the librarian designed and built a webbased tool called the Business Information Locator. The Business Information Locator consists of two connected parts: (1) a relational database of business reference sources that appear on the traditional pathfinders, and (2) a web site that allows the user to indicate the kind of business information he or she needs by selecting from menus in two categories, "Industry Information" or "Company Information," as shown in Figures 1 and 2. When the user checks one or more boxes to indicate the information needed and then clicks "Compile List," a CGL (common gateway interface) program written in Perl Generates an SQL query against the database of sources and returns a customized list of items that may be useful. The source list displays as a web page that is formatted for efficient printing and includes hypertext links where appropriate. In essence, users create pathfinders on the spot based on their information needs. An example of a source list generated from the database is shown in Figure 3.

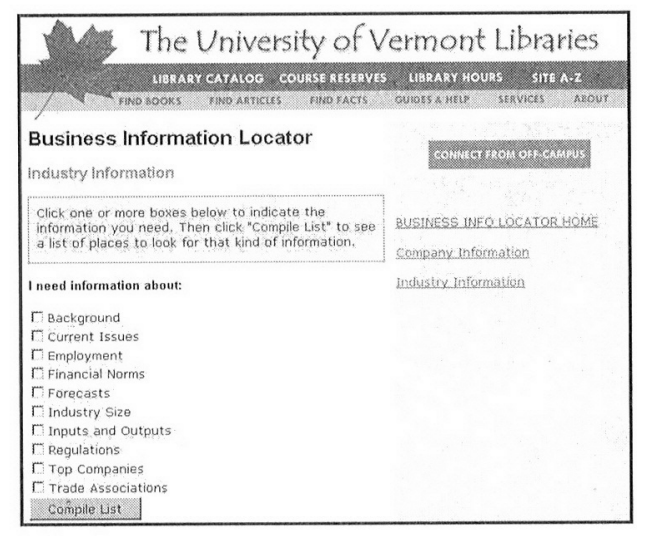

Figure 1. Menu for "Industry Information" Module 


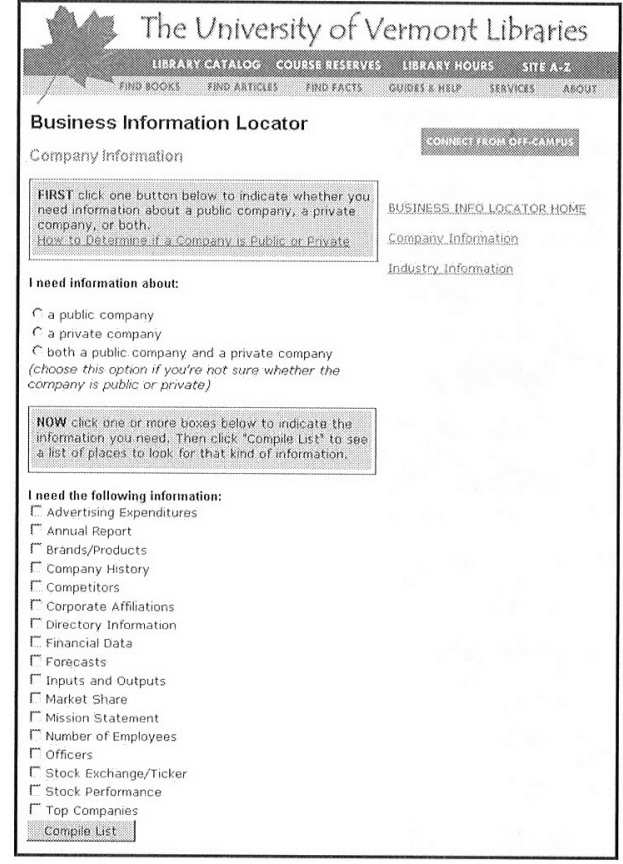

Figure 2. Menu for "Company Information" Module

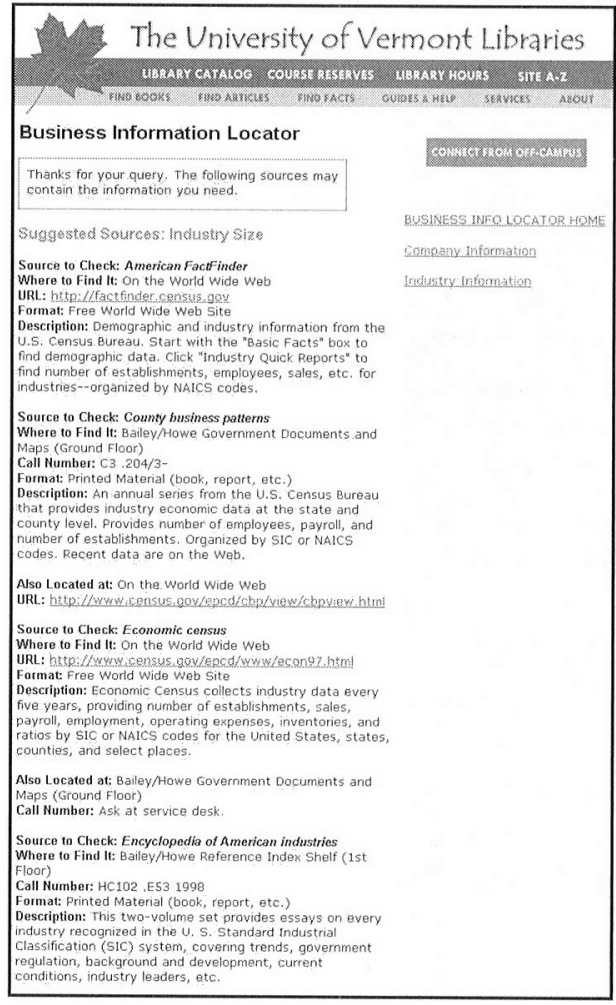

Figure 3. Sample Source List

It was hoped that the Business Information Locator would obviate the need to create and distribute a course-specific pathfinder for each of the many business library instruction sessions. Rather, the librarian could maintain a single database of business sources. Also, the locator would better serve the needs of librarians fielding questions at the reference desk. Preliminary discussions about the tool with reference librarians and instructional faculty were met with great enthusiasm, with many commenting that students are web-savvy and would probably prefer a web-based tool. While it is clear that the Business Information Locator offers several advantages for librarians, this study sought to determine whether the tool was at least as effective as the traditional pathfinder for students receiving library instruction.

\section{Literature Review}

Recent research affirms the belief that today's college students are heavy, experienced users of computers and the Internet. A Pew Research Center survey of 2,054 college students found that "by the time they were 16-18 years old, all of today's current college students had begun using computers." 2 Almost half of college students (47 percent) first began using the Internet before entering college, 74 percent use the Internet four or more hours per week, and 19 percent use it 12 hours or more per week. Seventy-three percent of students say they use the Internet more than the library for information searching. ${ }^{3} \mathrm{~A}$ Council on Library and Information Resources study of 3,234 faculty and students found 
that about half (49.2 percent) of undergraduates used electronic materials exclusively or almost exclusively. Reliance on electronic sources was even higher for business students, with 62.9 percent reporting use of electronic sources all or most of the time. ${ }^{4}$

In light of this information, academic librarians are often encouraged to make greater use of information technology in providing library instruction, and have responded by developing online tutorials, computer-assisted library classes, subject guides published on the web, and other technology-based tools. Furthermore, many librarians and library administrators believe that computer-assisted instruction offers advantages such as reliability and consistency, greater ability to reach more students, and time savings for librarians. ${ }^{5}$

It is not always clear, however, that these approaches are either preferred by students or yield improved library instruction outcomes. As Ransford Pyle and Charles Dziuban point out, "One of the dangers of recent advances in instructional technology is that instruction and instructors are often driven by technology rather than having technology serving the needs of instruction. ${ }^{\prime \prime}$ Although they were discussing use of the web in online and classroom instruction, the point is relevant to other applications of technology. Paul Doty cautions that libraries should not attempt to rebuild themselves to meet the technological expectations of students. He questions the idea that college students' expectations for college hang on the words "distance, digital, and virtual," and argues instead that students are expecting change and new experiences.?

Librarians who have tested technological approaches to instruction have found varying results. Stephanie Michel mentions numerous studies in which computer-assisted instruction was found to be at least as effective as more traditional forms. ${ }^{8}$ In her evaluation of a web-based library tutorial, she

Librarians who have tested technological approaches to instruction have found varying results. found that students were mostly positive about using the tutorial, but were ambivalent about having it replace traditional instruction." Carolyn Gutierrez and Jianrong Wang's study assigned one group of undergraduate students a printed library skills workbook and another group an electronic workbook, and then compared student attitudes and performance on pre- and post-tests. A greater proportion of students were satisfied with the electronic workbook, finding it user-friendly and easy. But the study found that format had no effect on students' performance on a post-test measuring library skills. In fact, the key determinant of performance was frequency of library use. ${ }^{10}$ Linda Alexander and Robert Smith compared student achievement and satisfaction with a traditionally taught, credit-bearing library skills course and the same course taught through WebCT. The study suggests that not all students prefer the web format, but that it is most favored by nontraditional (older, non-dorm) students. The study found no differences in student achievement related to the two formats. ${ }^{11}$ Hector Escobar Jr. et al. report that focus group and survey research at University Libraries of Notre Dame revealed that students were not interested in using an online library instruction tutorial, to the surprise of librarians and a libraries advisory council. ${ }^{12}$

Beginning before the advent of the Internet, libraries have also explored various technological approaches to library tours, including slide programs, videotape and au- 
diocassette tours, closed-circuit TV programs, HyperCard computer tours, and web tours, usually in an attempt to more efficiently use library staff and library instruction time. In a survey of ARL libraries, Lori Oling and Michelle Mach found that "despite the infiltration of technology into all other areas of the library, the most popular tour continues to be the traditional guided tour," offered by 93 percent of responding institutions. ${ }^{13}$ They advocate gathering more formal user feedback to better determine which formats are most effective, but say it "remains to be seen whether the virtual web tour will outlast its tour ancestors and match the popularity of the old-fashioned guided tour."it

According to Candice Dahl, traditional paper pathfinders are becoming increasingly popular in electronic form on library web sites. She states that these are especially useful for librarians on duty who are not familiar with the literature in a subject, and for people not in the library. ${ }^{15}$ Stephen Sloan believes that web pathfinders should not be mere copies of their paper counterparts. Instead, they should capitalize on the strengths and special capabilities of the web. He designed a virtual pathfinder that uses a CGI (common gateway interface) script to build an HTML document on the fly. When the user fills in a web form or chooses a subject, the script searches the library catalog and other web resources and returns a pathfinder that includes hypertext links to information on the Internet. According to Sloan, the virtual pathfinder is always up to date and puts a lighter burden on library staff, but he acknowledges that it imposes a burden on the user when it presents too many works or none at all. ${ }^{16}$

As these examples indicate, librarians should not assume that new approaches to library instruction are better for students simply because they are high-tech or are more convenient for librarians. Rather, librarians should test and assess these approaches to determine whether or not they are preferred by students and are more effective in achieving desired learning outcomes. Both Elizabeth Carter and Patricia Iannuzzi advocate outcome-focused performance assessments, not just measurements of user satisfaction, and urge collaboration with teaching faculty to determine relevant assessment measures. Useful measures include successful completion of assignments, pre- and posttests of competency, evaluation of student paper bibliographies, and review of portfolios or journals. ${ }^{17}$

\section{Research Questions}

This study sought to determine whether the Business Information Locator described above is as effective as a traditional pathfinder in helping business students complete research assignments for their classes. It compared the effectiveness of the two approaches by answering the following research questions:

1. Which approach contributes to greater student satisfaction with the in-class library instruction presentation?

2. Which approach are students more likely to use in their research?

3. How do students rate each approach on ease of use?

4. Which approach is perceived by students to be most helpful in conducting their research?

5. Which approach results in students citing a greater number of recommended business reference sources in their papers? 


\section{Methodology}

The study primarily used quantitative methods to address the five research questions, but used open-ended survey questions to generate qualitative data, as well. This combination allowed the researcher to gather data that can be generalized to the target population, and to amplify that data with more in-depth information about students' feelings, opinions, and attitudes.

\section{Target Population and Sample}

The study sought to gather information about undergraduate students enrolled in business courses that include assignments requiring business information research. Students enrolled in two sections of a core business course called "Management and Information Technology" served as the sample for the study. The study was conducted during the fall semester, 2002. At the start of the semester, Section A had 51 enrolled students and Section B had 51 enrolled students. At the end of the semester, enrollment was 52 and 49 respectively. Both sections were taught by the same professor, covered the same content, and used the same syllabus and assignments. Students were required to work in groups of four to complete research papers about a company, its industry, and the company's use of information technology. Each section of the course generated 12 research papers, for a total of 24 .

This sample was chosen for several reasons. First, having access to two sections of the same course with students completing the same research assignment allowed for an experimental research design, in which one section received library instruction using the traditional pathfinder, and the other section received library instruction using the Business Information Locator. Second, the fact that most students in this course were first-year students meant it was unlikely that they had received previous college library instruction that may have influenced the results. Third, because the course is required of all business students, students represented a diversity of business majors including accounting, marketing, international business, and entrepreneurship.

Selection bias is always a concern in studies comparing two groups. Although students were not randomly assigned to the two course sections, the following factors minimized the potential for students in the two sections to be significantly different from each other: (1) All students in the business school - and in this class - are required to own computers, so students in both sections had equal access to computers; (2) Both sections of the class were open for registration at the same time, so it is not the case that all students who were late to register ended up in one class; (3) Both sections were taught by the same teacher, so neither section had students who desired a teacher with a reputation for being "easy" or "more difficult;" (4) At the time of enrollment, students were not aware that the two sections would receive different library instruction research tools; (5) Both sections met in the same building and in the same room, so students should not have been different in their desire for a comfortable setting; and (6) Both sections were taught on the same day. The sections did, of course, meet at different times-9:30 a.m. and 11:30 a.m.-but the librarian believes that these times are similar enough so as not to present a significant risk of selection bias. 


\section{Data Collection and Analysis}

The librarian visited each section of the business course on the same day, and presented a 75-minute library instruction session on business research. The session offered general tips for doing research, covered the use of industry codes in doing research, and used hands-on exercises to introduce recommended business reference sources including books, web sites, and subscription databases. Students in Section B received a traditional print pathfinder at the start of the session, and were advised to use it as a tool in finding sources for their research. Students in Section A saw a demonstration of how to use the Business Information Locator to identify sources for their research. They did not receive the traditional pathfinder, but instead received a handout that outlined the major steps in the research process and provided the URL and a brief description of the Business Information Locator.

Several methods were used to collect data concerning the research questions:

1. At the end of the library instruction session, students in both sections were given 10 minutes to complete a written survey about the session. The survey included open- and closed-ended questions, and asked students to anonymously evaluate the quality of the library instruction presentation in terms of relevance to the assignment, ease of understanding, amount of material covered, and usefulness. Results from the two sections were compared to determine whether the use of the Business Information Locator rather than the traditional print pathfinder had any negative or positive impact on students' opinions about the library instruction session.

2. In the class session preceding the day that students' research projects were due, the course instructor asked students to complete a second written survey about either the traditional pathfinder or the Business Information Locator. The survey asked students to report anonymously how much they used the tool they were given and to evaluate its usefulness and ease of use. The survey included both open- and closed-ended questions, and was distributed during class by the professor, without the librarian present. Results from the two sections were compared to determine which tool received higher ratings and was more heavily used by students. (The book Evaluating Library Instruction, edited by Diana Shonrock, was helpful in developing questions for both surveys. $)^{18}$

3. As part of the research paper assignment, students were required to cite their information sources in the text of their papers and include a bibliography of those sources. After receiving all 24 papers, the professor photocopied the student paper bibliographies, grouped them by course section, and forwarded them to the librarian. The librarian reviewed the bibliographies, counted the number of recommended reference sources included in each, and calculated an average number of sources for each of the course sections. Results from the two sections were compared to determine whether the Business Information Locator was as effective as the traditional pathfinder in encouraging students to use and cite recommended reference sources. 


\section{Limitations and Controls}

The study methodology has several limitations. Cross-contamination between the two samples was possible, with students in the two sections exchanging information and research tips. For example, a student in the section that received the traditional pathfinder could make a photocopy of the pathfinder and share it with a student in the section that had been advised to use the Business Information Locator. The study design minimized this problem by sampling mostly first-semester, first-year students who are less likely to know many students outside their classes.

It is possible that some students would cite a greater number of recommended reference sources simply because the company and industry they chose to research are covered by a greater number of sources, and not because the students made greater use of the traditional pathfinder or the Business Information Locator. To control for this, student groups in each course section were assigned companies for their research projects. The librarian screened the companies and industries to make sure that information about them was available in standard business library reference sources, so both course sections had a similar chance of citing recommended reference sources.

\section{Respondent Profile}

Of the 102 students enrolled in the course at the beginning of the semester, 86 completed the first survey immediately after the class presentation for an 84 percent response rate. Eighty-four students completed the second survey for an 82 percent response rate. The respondent profile that follows is based on data gathered in the first survey. Both sections were predominantly male (72.3 percent in Section A; 64.1 percent in Section B) and composed mostly of first-year students (87.2 percent in Section A; 66.7 percent in Section $B$ ). A majority of students in both sections had received no library instruction sessions in other courses (70.2 percent in Section A; 68.4 percent in Section $B)$. Both sections included a substantial number of students who were undecided about their area of major concentration (29.8 percent in Section A; 41.0 percent in Section B).

On a seven-point scale where " 7 " means extremely confident, students in each section reported a high degree of confidence using computers (mean score of 5.8 in Section A; mean score of 5.5 in Section B). On the same scale, students reported less confidence in using the library (mean score of 4.7 in Section A; mean score of 4.6 in Section B). More than one-third of the students in each section rated their confidence in using the library a "4" or lower.

Reported use of the library during the previous school year varied considerably among students, but was consistent across the two sections. About half the students in each section used the library every day or once a week during the previous school year, and fewer than 10 percent never used the library (table 1). Students in both sections are heavy users of computers, making frequent use of the World Wide Web and e-mail, moderate use of word processing programs, and infrequent use of spreadsheet programs (table 2). 


\section{Table 1}

\section{Percent of Students Using Library During the Last Year}

\begin{tabular}{lcc}
\hline & $\begin{array}{c}\text { Section A } \\
\text { Business Information Locator }\end{array}$ & $\begin{array}{c}\text { Section B } \\
\text { Traditional Pathfinder }\end{array}$ \\
\hline Used library every day or once a week & $46.7 \%$ & $50 \%$ \\
Used library once or twice a month & $22.2 \%$ & $26.4 \%$ \\
Used library less than once a month & $24.4 \%$ & $15.8 \%$ \\
Never used the library & $6.7 \%$ & $7.9 \%$ \\
\hline
\end{tabular}

\section{Table 2}

\section{Percent of Students Using Computer Applications}

\begin{tabular}{llcc}
\hline & \multicolumn{1}{c}{$\begin{array}{c}\text { Section A } \\
\text { Business Information Locator }\end{array}$} & $\begin{array}{c}\text { Section B } \\
\text { Traditional Pathfinder }\end{array}$ \\
\hline World Wide Web & Use Daily & $100 \%$ & $100 \%$ \\
E-Mail & Use Daily & $95.7 \%$ & $92.3 \%$ \\
Word Processing & Use Weekly & $4.3 \%$ & $7.7 \%$ \\
& Use Daily & $54.3 \%$ & $59 \%$ \\
Spreadsheets & Use Weekly & $45.7 \%$ & $41 \%$ \\
& Use Daily & $4.4 \%$ & $5.1 \%$ \\
& Use Weekly & $51.1 \%$ & $48.7 \%$ \\
& Use Monthly & $24.4 \%$ & $25.6 \%$ \\
Have Created a & Rarely Use & $20.0 \%$ & $15.4 \%$ \\
Web Page & Never Use & $0 \%$ & $5.1 \%$ \\
& & & $36.8 \%$ \\
\hline
\end{tabular}

Chi-square and Mann-Whitney tests showed that the difference between the two sections was statistically significant on only one of the above-described characteristics, the proportion of first-year students. Section A consisted of a significantly greater proportion of first-year students, while Section B consisted of a correspondingly greater proportion of second-year and higher students $(p=.035)$. The two sections were not significantly different in any other area - sex, area of major concentration, number of 
library instruction sessions previously attended, use of the library in the previous year, confidence using the library, or confidence using computers and computer applications.

\section{Results}

\section{Satisfaction With Class Presentation}

The first survey revealed no significant difference between the scores of the two sections in terms of student satisfaction with the class presentation (table 3). (Because the data were not normally distributed, a non-parametric Mann-Whitney Test was used to compare medians, $\mathrm{p}>$.05.) More than 90 percent of respondents in each section expressed agreement (" 5 " or higher on a 7-point scale) on all four attributes of the presentation: (1) It covered the kinds of information needed to complete the class project; (2) It was easy to follow; (3) It made students feel more confident about successfully completing the class project; and (4) The amount of material covered was appropriate for the time allotted.

\section{Table 3}

\section{Mean Scores on Class Presentation}

(on a 7 -point scale where $1=$ strongly disagree and $7=$ strongly agree)

\begin{tabular}{lcc}
\hline & $\begin{array}{c}\text { Section A } \\
\text { Business Information Locator }\end{array}$ & $\begin{array}{c}\text { Section B } \\
\text { Traditional Pathfinder }\end{array}$ \\
\hline Presentation covered information I need & 6.3 & 6.1 \\
Presentation was easy to follow & 6.2 & 6.1 \\
Presentation made me feel more confident & 6.1 & 6.2 \\
Amount of material covered was appropriate & 6.2 & 6.2 \\
\hline
\end{tabular}

Students in the two sections gave strikingly similar responses to the open-ended questions on the survey. When asked what they found most helpful about the instruction session, students most often gave responses related to the number and availability of business information sources. Examples from students in Section A who received the Business Information Locator include: "Told where to find everything I need for my paper," "I learned how to use sources I never knew existed," and "It will be easier to get info for the company now." Students in Section B who received the traditional pathfinder offered the following: "The new info that will make me more efficient," "It provided me with many ideas of where I can begin my research that I didn't know prior to this presentation," and "The amount of resources conveniently located." Many students in both sections also indicated that they found especially helpful the web sites 
and databases that were demonstrated, including the library catalog and the EDGAR database of Securities and Exchange Commission filings.

When asked what they found confusing or difficult to understand, a majority of students responding in both sections said "nothing." In both sections, small numbers of students mentioned industry codes and techniques of online searching, such as truncation.

Finally, when asked for comments or suggestions about the presentation, students in both sections were overwhelmingly positive. Many students said they felt the presentation was helpful and made them feel more confident about completing their projects: "Very informative, now I am less stressed out about the info I need to find," "Presentation was very good and helped me a lot," "Good presentation. Helped me a lot on where to start looking for information," "It was helpful. I feel I have more resources to do my project with."

\section{Use of and Satisfaction With Research Tool}

Students in the two sections differed markedly in their responses to the second survey, which measured use of and satisfaction with their respective research tool (either the Business Information Locator or the traditional pathfinder). On every measure, students who received the traditional pathfinder rated it more highly than students who received the Business Information Locator: (1) level of use, (2) ease of use, (3) effectiveness in helping the student find useful information, (4) clarity in explaining where information was physically located, and (5) usefulness for other classes (table 4). A Mann-Whitney test showed that each of these differences was significant, with only one exception: the tool made it clear where information was physically located.

\section{Table 4}

\section{Mean Scores on Research Tool}

(on a 7 -point scale where $1=$ strongly disagree and $7=$ strongly agree)

\begin{tabular}{lccc}
\hline & $\begin{array}{c}\text { Section A } \\
\text { Business Information } \\
\text { Locator }\end{array}$ & $\begin{array}{c}\text { Section B } \\
\text { Traditional } \\
\text { Pathfinder }\end{array}$ & p value \\
\hline $\begin{array}{l}\text { Used the tool extensively* } \\
\text { Tool was easy to use* }\end{array}$ & 4.3 & 5.6 & .000 \\
$\begin{array}{l}\text { Tool helped me find useful information* } \\
\text { Tool made it clear where information was }\end{array}$ & 4.3 & 6.0 & .000 \\
$\quad$ physically located & 5.0 & 6.2 & .001 \\
$\begin{array}{l}\text { Would use tool to complete similar assignment } \\
\text { in another class* }\end{array}$ & 5.1 & 5.7 & .071 \\
& 5.1 & 5.8 & .012 \\
* Difference between two sections is statistically significant. & & \\
\hline
\end{tabular}


Students' ratings of the Business Information Locator were particularly low in two areas: level of use and ease of use. Only 66 percent of respondents who received the Business Information Locator reported giving it moderate or extensive use (" 4 " or higher on a 7-point scale). In contrast, 92.5 percent of respondents who received the traditional pathfinder reported using it moderately or extensively. Only 41 percent of respondents who used the Business Information Locator gave it a positive rating on ease of use (" 5 " or higher on a 7-point scale), compared to 84.7 percent of respondents using the traditional pathfinder.

When asked if the research tool helped them find useful information, 59 percent of respondents using the Business Information Locator rated it "5" or higher on a sevenpoint scale, compared to 89.7 percent of respondents using the traditional pathfinder. Respondents using the pathfinder also said they were more likely to use it again to complete similar assignments in other classes. On a seven-point scale, 82.5 percent of them rated the likelihood at " 5 " or higher, compared to 63.7 percent of respondents using the Business Information Locator.

Students' responses to open-ended questions help illuminate these results. Half of the respondents who received the Business Information Locator but reported not using it said that they found enough information without it. Several students claimed they had tried to use the Business Information Locator but "got nowhere," "did not know what to do," or "found it difficult to find the exact information I needed." This suggests that students were confused about what to expect from the tool; perhaps they thought it would lead them to actual data instead of providing a list of sources to check.

When asked what was most confusing or not useful about the tool they were given, almost half the respondents who received the printed pathfinder said "nothing." Only four of the respondents who re-

When asked what was most confusing or not useful about the tool they were given, almost half the respondents who received the printed pathfinder said "nothing." ceived the Business Information Locator gave that answer. Many students who received the Business Information Locator said that the tool was too broad, listed too many sources of information, or listed sources that were not relevant to their project. In contrast,

only one student in the section that received the traditional pathfinder offered a similar remark.

It should be noted, however, that many students did use the Business Information Locator and found it helpful, as the following examples indicate:

- "It helped me find sources that I would never have known about to look for."

- "The most useful part of it was the definition of what each book or source was about."

- "It was easy to use and supplied very useful information from a lot of different sources."

- "The most useful part of the locator was the breakdown within the site of the topics. I found that I could find what I needed very quick." 
- "The BIL was easy to use once I was told how to use it. All that I needed was there (I didn't have to struggle) and it made research not seem so bad."

\section{Quality of Students' Bibliographies}

Analysis of the bibliographies of the final papers was unable to disprove the null hypothesis - that there is no difference between the two sections in the number of recommended reference sources cited. The bibliographies show that students in both sections relied heavily on free World Wide Web sites not demonstrated or recommended by the librarian. In addition to these free web sites, student groups who were instructed to use the Business information Locator cited an average of 3.8 recommended business reference sources. Student groups who received the traditional pathfinder cited an average of 5.8 recommended business reference sources.

Although the mean scores appear to indicate that students who received the pathfinder made greater use of library reference materials, it must be noted that one of the papers from this section cited 19 recommended sources, far more than any other paper. This one data point was very influential in pulling the mean up to 5.8. If this single paper had been more similar to the other papers in the section, the difference between the mean scores of the two sections would have been far less dramatic. For example, if the paper had cited 5 sources instead of 19 , the mean would have been 4.6 instead of 5.8. Furthermore, a Mann-Whitney Test revealed that the difference between the two sections was not statistically significant $(\mathrm{p}=137)$. The use of the Business Information Locator instead of the traditional pathfinder had no negative effect on the quality of students' bibliographies, as measured by the number of recommended business reference sources cited.

\section{Discussion}

The results clearly show that the use of the Business Information Locator rather than the printed pathfinder had no negative impact on students' opinions about the library instruction session. Students in both sections gave the presentation high marks and said it made them feel more confident about completing their research projects.

On ease of use and level of use, however, students who received the traditional pathfinder gave the tool higher ratings than students who received the Business Information Locator. Students using the pathfinder were quite consistent in commenting that the tool was helpful, clear, and easy to use. In contrast, students who received the Business Information Locator were divided in their reactions to the tool; many gave it high praise, but many others expressed confusion and frustration. This suggests that the traditional pathfinder may be preferred by a greater number of students than the webbased tool. This result also indicates, however, that for many students the Business Information Locator was not a failure. Students' comments indicate that many found it easy to use and helpful.

Students receiving the Business Information Locator also gave the tool lower marks for helpfulness than did students receiving the pathfinder. Many students using the Business Information Locator complained that the suggested information sources were not relevant to their projects, an opinion expressed by only a single student receiving 
the traditional pathfinder. This result is especially interesting because the pathfinder and the Business Information Locator contain the same sources. This may indicate that students approach a web-based tool with different expectations than they do a printed pathfinder, and are therefore more easily frustrated and disappointed. Perhaps when students go the web, they expect to read full-text content that will answer their questions. If that is true, it is possible that when students used the Business Information Locator and received a list of sources to check-rather than immediate answers to their business research questions-they were confused. It is also possible that students expect more sophisticated search functionality when they use web-based tools, and were disappointed to see menus of topic areas to choose from. As one user of the Business information Locator put it, "Navigation would have been a bit easier if I could have simply typed in my company's name." In contrast, the size and format of the printed pathfinder give strong clues that it doesn't actually contain business information, but that it's a guide or instruction sheet for doing business research. Further study might verify that the tangible nature of the printed pathfinder helps students more clearly and readily understand its purpose, functionality and scope.

While it is interesting to consider students' opinions about the two tools, it is probably more important to evaluate the impact of the tools on learning outcomes and student scholarship. The analysis of student bibliographies showed no significant difference between the two sections. On average, students who received the Business Information Locator cited the same number of business reference sources as students who received the traditional pathfinder. Fur-

\section{While it is interesting to consider students' opinions about the two tools, it is probably more important to evaluate the impact of the tools on learning outcomes and student scholarship.} thermore, students in both sections cited a large number of free web sites and freely available newspaper articles. This result suggests that the format of the tool-either a traditional pathfinder or the wcb-based locator-has little effect on students' use of recommended business reference materials. If librarians and teaching faculty want students to use and cite these materials to a greater degree,

they must use other techniques and incentives to encourage students. For example, faculty might require a certain number of library sources to be consulted, limit the number of free web sites that students may use, or create assignments that cannot be successfully completed without the use of business reference sources. In a longitudinal study of student citation behavior, Philip Davis found that students' use of scholarly materials (books and journals) increased after a professor implemented enforceable guidelines for acceptable reference sources. ${ }^{19}$

\section{Conclusion}

This study demonstrates that librarians should not assume students will prefer webbased research aids and use them more heavily. In spite of students' high level of confi- 
dence and experience with computers and the web, they rated the traditional print pathfinder easier to use and more helpful than the web-based finding tool, and they gave it greater use. This finding seems to suggest that the librarian would best serve students by continuing to distribute print pathfinders.

However, students' ratings of these tools did not appear to impact the desired learning outcome-that students will cite recommended business reference sources in their papers. Students cited a similar number of sources, regardless of the tool they used. This finding leads to a different conclusion: The librarian could replace traditional print pathfinders with the web-based finding tool, with no ill effect on student scholarship. This would free up valuable time that is now spent updating numerous business pathfinders. That time would be better invested in collaboration with the teaching faculty, devising ways to make sure students use credible business reference sources.

The case for replacing the traditional print pathfinders with the Business Information Locator becomes even more compelling when one considers the fact that the Locator can help students find business information in subsequent courses. Having learned to use the tool during their first year, students can turn to it as needed throughout their college careers, knowing it will always be up-to-date. This study measured students' opinions based on exposure to the Business Information Locator in a single course. It is possible that students' opinions would improve with additional practice using the toolprovided they chose to use it again. If that is true, the Business Information Locator may be a better choice for students long-term, even if it is more difficult for them initially.

To be fully effective for business students enrolled in a wide range of courses, however, the Business Information Locator must be expanded to include additional modules such as marketing and demographics, money and finance, and operations. It would then serve as a useful research tool for all business students, while scrving the needs of reference librarians and business school faculty, as well.

Finally, the study reveals the limitations of quantitative research. Additional qualitative usability testing or focus group research would help identify ways to improve the web-based finding tool and make it more user friendly for students. For example, something as simple as giving the tool a different name might clarify for students the scope of the tool and reduce their frustration. Such research should be undertaken before discontinuing the use of print pathfinders.

\section{Acknowledgements}

The author wishes to acknowledge the following: Marilyn Lucas for her collaborative spirit and advice; Alan Howard for his help with statistical analysis; Daisy Benson and Lyman Ross for their technical assistance in creating the Business Information Locator; and Meredith Butler and Laurie Kutner for their review of the study proposal and draft.

Trina J. Magi is an assistant professor at the University of Vermont Bailey/Howe Library; she may be contacted via e-mail at: trina.magi@uom.edu. 


\section{Notes}

1. In library instruction evaluations completed by students in University of Vermont business classes during the 2001-2002 academic year, 96 percent of students agreed or strongly agreed that the printed pathfinders were helpful to them.

2. Pew Research Center, "The Internet Goes to College: How Students Are I iving in the Future with Today's Technology" (September 15, 2002). Available: <http:// www.pewinternet.org/reports/pdfs/PIP_College_Report.pdf> [September 16, 2003].

3. Ibid.

4. Council on Library and Information Resources, "Dimensions and Use of the Scholarly Information Environment: Introduction" (2002). Available <http:/ / www.clir.org/pubs/ reports/pub110/introduction.html> [September 16, 2003].

5. Stephanie Michel, "What Do They Really Think? Assessing Student and Faculty Perspectives of a Web-based Tutorial to Library Research," College and Research Libraries 62, 4 (July 2001): 319.

6. Ransford C. Pyle and Charles D. Dziuban, "Technology: Servant or Master of the Online Teacher?" Library Trends 50, 1 (Summer 2001): 130.

7. Paul Doty, "Fish, Fire, and Fallacies: Approaches to Information Technology and Higher Education," portal: Libraries and the Academy 2, 4 (October 2002): 647-648.

8. Michel, 321 .

9. Ibid., 329 .

10. Carolyn Gutierrez and Jianrong Wang, "A Comparison of an Electronic vs. Print Workbook for Information Literacy Instruction," The Joumal of Academic Librarianship 27, 3 (May 2001): 210-211.

11. Linda B. Alexander and Robert C. Smith, "Research Findings of a Library Skills Instruction Web Course," portal: Libraries and the Academy 1, 3 (July 2001): 309-328.

12. Hector Escobar Jr., Joni Kanzler, G. Margaret Porter, and Cheryl Smith, "The Value of Campus Partnerships in Redesigning Library Instruction," College and Research Libraries News 63, 5 (May 2002): 347.

13. Lori Oling and Michelle Mach, "Tour Trends in Academic ARL Libraries," College and Research Libraries 63, 1 (January 2002): 22, 21.

14. Ibid., 22

15. Candice Dahl, "Electronic Pathfinders in Academic Libraries: An Analysis of Their Content and Form," College and Research Libraries 62, 3 (May 2001): 227.

16. Stephen Michael Sloan, "The Virtual Pathfinder: A World Wide Web Guide to Library Research," Conputers in Libraries 16, 4 (April 1996): 53-54.

17. Elizabeth W. Carter, "Doing the Best You Can with What You Have: Lessons Learned from Outcomes Assessment," The Joumal of Academic Librarianship 28, 1/2 (January/March 2002): 36-41; Patricia Iannuzzi, "We Are Teaching, But Are They Learning: Accountability, Productivity, and Assessment," The Journal of Academic Librarianship 25, 4 (July 1999): 304305.

18. Diana D. Shonrock, ed., Evaluating Library Instruction, Sample Questions, Forms, and Strategies for Practical Use (Chicago: American Library Association, 1996).

19. Philip M. Davis, "Effect of the Web on Undergraduate Citation Behavior: Guiding Student Scholarship in a Networked Age," portal: Libraries and the Academy 3, 1 (January 2003): 47. 